\title{
ASSESSMENT OF GENETIC VARIATION OF TILIA TOMENTOSA BY RAPD MARKERS
}

\author{
Iulian GABUR ${ }^{1}$, Florin Daniel LIPȘA ${ }^{1}$, Lidia ADUMITRESEI ${ }^{2}$, Cătălin TĂNASE $^{3}$, \\ Dănuț Petru SIMIONIUC $^{1 *}$
}

${ }^{1}$ Department of Plant Sciences, Faculty of Agriculture, University of Agriculture Sciences and Veterinary Medicine "Ion Ionescu de la Brad", Iași - Romania

${ }^{2}$ Biologic section, "Anastasie Fătu” Botanic Garden, Iaşi - Romania

${ }^{3}$ Department of Biology, Faculty of Biology, "Alexandru Ioan Cuza" University of Iaşi - Romania

* Corresponding author. E-mail: simion@uaiasi.ro

\begin{abstract}
Tilia tomentosa varieties were analyzed using Random Amplified Polymorphic DNA (RAPD) primers to determine genetic diversity. In this study, six samples provided by the Botanical Garden "Anastasie Fătu" of Iasi, Romania were compared to a variety collected from an ecosystem in Giessen, Germany. A total of 91 bands were obtained from nine RAPD primers, 79 (86.8\%) of which were polymorphic. Marker data was used for a principal component analysis that showed clear differentiation among Romanian and German samples. Furthermore, Romanian genotypes were clustered together in the principal component analysis. PCA analysis was followed by an Unweighted Pair Group Method with Arithmetic Mean (UPGMA) cluster analysis which revealed two major groups. Samples from the Romanian ecosystem showed high genetic similarity. Generally, samples did not separate from each other in the UPGMA analysis, excepting the German sample.
\end{abstract}

Keywords: DNA, genetic diversity, principal component analysis, silver lime tree, UPGMA cluster analysis.

\section{Introduction}

Trees of the genus Tilia L. (Malvaceae) can be found in urban and forest ecosystems especially in the northern hemisphere in Europe, but also in Asia and Northeastern and Central America. Due to their polymorphism as well as a large number of transitional forms and hybrids, more than 60 species of Tilia are reported [WERYSZKO-CHMIELEWSKA \& al. 2019]. The Plant List website reports more than 45 accepted Tillia species and a number of 477 lines and hybrids. This genus grows in temperate, subtropical and tropical climates and occurs from moist to dry regions [MUIR, 1984]. Linden trees could act as noise filters and purify the air through capturing the pollutants originating from traffic and different industrial activities. They reduce flooding and damage to urban property during stormwater runoff and also urban heat intensity [SJÖMAN \& al. 2012]. As a result, representatives of these genera became increasingly important for local Romanian landscapes, in municipal parks in large cities or as avenue trees [SUKOPP \& WURZEL, 2000].

In many European cities, growing damages of Tillia tomentosa Moench trees are caused by abiotic stress factors like salt and drought [Helsinki: TERHO \& HALLAKSELA (2005), Warsaw: CHMIELEWSKI \& al. (1998), Budapest: SINKO (2005)]. For this reason, in Europe since the 1960s T. cordata Mill. and T. platyphyllos Scop. were increasingly replaced by $T$. tomentosa Moench and T. $\times$ euchlora K. Koch originating from Southeastern Europe and the Caucasian region. These varieties are better adapted to urban conditions in Central Europe. Nowadays, breeding efforts should focus more on better adapted plant 
material to ever-changing climatic challenges as high drought stress resistance, saltresistance and tolerance to soil compaction for urban areas occur. (KARNOSKY \& al. 1982).

\section{Material and methods}

\section{Plant material}

Leaf material was collected from "Teiul lui Eminescu" ("Eminescu's Linden") - an emblematic 500-year old tree for Romanian culture, being set in Copou Park in Iaşi, Romania (P5 in Table 1), three putative clones of P5 (P1 and P2 - cultivated in the Botanical Garden "Anastasie Fătu" of Iaşi since 1981 - in Table 1), P3 - being a clone of P1, cultivated in the Botanical Garden "Anastasie Fătu" of Iaşi since 2012 and offered by the city officialities to the people of Wien and a T. cordata Mill. sample (P4 in Table 1) available at the Botanical Garden of Iaşi, Romania, a T. tomentosa Moench samples from USAMV-Iaşi, Romania (P6, in Table 1) and one extra sample of T. $\times$ euchlora K. Koch collected from Giessen, Germany (P7 in Table 1). All samples from Iasi are very close to T. tomentosa regarding morphological traits, while P4 was identified previously as T. cordata and P7 as T. $\times$ euchlora by morphological traits. T. $\times$ euchlora (Caucasian or Crimean linden) is a hybrid whose parentage is unclear but is considered $T$. cordata and $T$. dasystyla. The different species far distant from the putative relatives of the interesting clones were integrated as outgroups to test the reliability of the analytic methods.

Table 1. Plant material collection of genera Tilia, including clones

\begin{tabular}{|c|c|c|c|}
\hline No. & Species & Abbreviation & Location \\
\hline 1. & T. tomentosa & P1 (Clone) & Botanic Garden “Anastasie Fătu”, Iaşi, RO \\
\hline 2. & T. tomentosa & $\begin{array}{l}\text { P2 (Clone - atypical } \\
\text { appearance) }\end{array}$ & Botanic Garden “Anastasie Fătu”, Iaşi, RO \\
\hline 3. & T. tomentosa & P3 (Clone) & Botanic Garden “Anastasie Fătu”, Iaşi, RO \\
\hline 4. & T. cordata & P4 & Botanic Garden “Anastasie Fătu”, Iaşi, RO \\
\hline 5. & T. tomentosa & $\begin{array}{l}\text { P5 (Teiul lui Eminescu- } \\
\text { Eminescu's Linden) }\end{array}$ & $\begin{array}{l}\text { Parcul "Mihai Eminescu", Iaşi, RO } \\
\text { ("Mihai Eminescu" Park) }\end{array}$ \\
\hline 6. & T. tomentosa & P6 & USAMV "Ion Ionescu de la Brad", Iaşi, RO \\
\hline 7. & T. euchlora & P7 (Krimlinde) & Lonystrasse, Giessen, DE \\
\hline
\end{tabular}

\section{Random Amplified Polymorphic DNA (RAPD) analysis}

Fresh tissues were harvested in September 2017 in Iasi and Giessen. Leaves were frozen in liquid nitrogen and homogenized. DNA was isolated following the Doyle and Doyle DNA extraction protocol [DOYLE \& DOYLE, 1990] DNA extraction efficiency was evaluated using the Qubit ${ }^{\mathrm{TM}}$ Fluorometer (Thermo Fisher Scientific Inc., USA) and NanoDrop ${ }^{\mathrm{TM}} 2000$ spectrophotometric assays (Thermo Fisher Scientific Inc., USA) for specifically quantitate DNA.

A standard protocol was used to carry out the RAPD analysis. As a preliminary study, 12 arbitrary primers (Operon Technologies Inc., USA) were used for the amplification (Table 2). From these 12 primers, nine were selected for Polymerase Chain Reaction (PCR). PCR was 
Iulian GABUR \& al.

performed in $20 \mu \mathrm{l}$ reaction volume containing 10-20 ng template DNA, dNTP mix $(200 \mu \mathrm{M}$ each nucleotide), $0.25 \mu \mathrm{M}$ primer, reaction buffer (including $\mathrm{MgCl}_{2}$ to a final concentration of $2.5 \mathrm{mM}$ ) and 1 Unit Taq DNA polymerase (Thermo Fisher Scientific Inc., USA).

The amplification reactions were carried out in a Thermocycler (Bio-Rad Laboratories, Inc., USA) with the following program: Initial denaturation 3 minutes at $94{ }^{\circ} \mathrm{C}$; 35 cycles with 1 min $94{ }^{\circ} \mathrm{C}$ denaturation, $1 \mathrm{~min} 35^{\circ} \mathrm{C}$ annealing, $1 \mathrm{~min} 72{ }^{\circ} \mathrm{C}$ elongation; final extension $10 \mathrm{~min} 72{ }^{\circ} \mathrm{C}$; hold $4{ }^{\circ} \mathrm{C}$.

PCR products were separated in $1 \%$ agarose gel with $1 \times$ Tris-borateEthylenediaminetetraacetic acid (EDTA) (TBE) - Life Technologies buffer. The gels were previously run at $120 \mathrm{~V}$ for 2 hours and afterward were digitally photographed under UV light. The used marker was a 100-bp DNA ladder (Thermo Fisher Scientific Inc., USA). Replications of DNA extraction and amplification were performed with relevant primers and a subset of samples to confirm reproducibility.

Table 2. Molecular markers used for RAPD analysis of Tilia specimens

\begin{tabular}{ccc}
\hline No. & Primer code & Sequence (5'-3') \\
\hline 1. & R5 & CTG GGG CTG A \\
2. & R8 & GGT GGT GAT G \\
3. & R9 & AAA GTG CGG C \\
4. & R12 & AAT GCG GGA G \\
5. & R17 & TGC TCT GCC C \\
6. & R18 & GGT GAC GCA G \\
7. & L 12 & GGG CGG TAC T \\
8. & OPA 03 & AGT CAG CCA C \\
9. & OPB 10 & CTG CTG GGA C \\
10. & OPE 20 & AAC GGT GAC C \\
11. & OPG 14 & GGA TGA GAC C \\
12. & OPD 11 & AGC GCC ATT G \\
\hline
\end{tabular}

\section{Data analysis}

The RAPD bands were scored as present (1) or absent (0). A matrix of similarities between every pair of individuals was obtained by using the Euclidean distance index [GOWER, 1985]. Principal component analysis (PCA) was performed using the RAPD relationship between individuals using the R-code 3.3.3 (R Core Team, 2018) software and the "prcomp" function [VENABLES \& RIPLEY, 2002]. Additionally, a dendrogram was generated based on Euclidean's similarity coefficients using the unweighted pair group method with calculating the arithmetic average (UPGMA) by R-code, "agnes \{cluster\}". 


\section{Results and discussions}

A total of 12 RAPD primers were tested and nine of them produced suitable and reproducible banding patterns. We obtained 91 fragments that could be scored and used for further analysis. Out of the 91 fragments, 79 were polymorphic with an average of 8 polymorphic fragments per primer. The highest number of polymorphic bands (12) was obtained with primer L12 and R18, whereas the lowest number of bands was obtained with primers R5 (5) and OPG 14 (6).

Based on UPGMA analysis, two major groups were observed: P4 and P7 clustered together with a major group, whereas the other 6 genotypes were grouped together in another major group (Figure 1). The T. tomentosa clonal genotypes (P1, P2, P3 indicated in black color) were clustered together with the P5 ("Teiul lui Eminescu") genotypes in the first major group. Notably, the highest similarity value was found to be between genotype P1 and genotype P5. The dendrogram was in accordance with the geographic distributions of Tilia genotypes, by separating sample P4 and P7 from the group from Iaşi.

Cluster Dendrogram

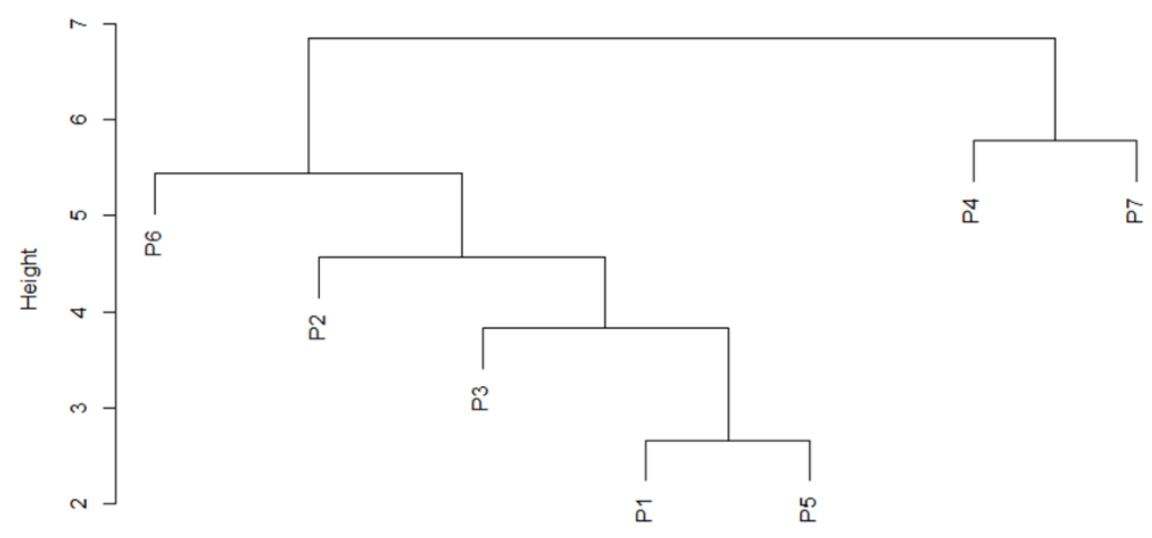

Figure 1. Dendrogram using the unweighted pair group method with calculating the arithmetic average (UPGMA) cluster analysis based on Euclidean similarities of 7 Tilia genotypes by using RAPDs (Abbreviations see Table 1).

PCA was performed to visualize the genetic relationship between Tilia genotypes (Figure 2). The first two principal components explain a large proportion of genotypic variance present in the data set, namely $46.2 \%$ (PC1) and $16.4 \%$ (PC2). A wide range distribution profile with two subplots with Tilia genotypes was obtained. Two subplots comprised Iasi genotypes (1), whereas the other one (2) comprised the genotypes from Giessen. 


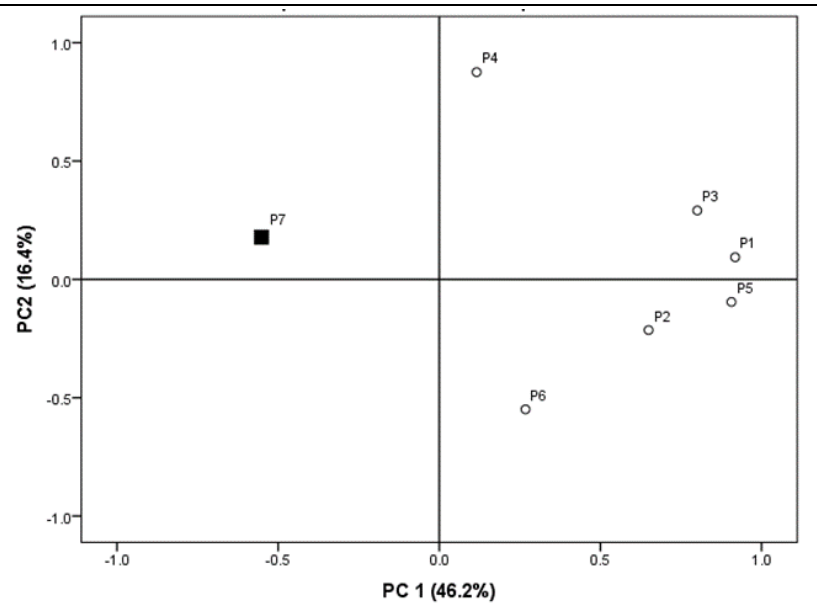

Figure 2. Principal component analysis plot of the RAPDs data among 7 genotypes of Tilia

In-plant sciences, biological diversity can be separated into three levels, such as genetic diversity, species diversity and ecosystem diversity [RAO \& al. 2002]. Nowadays, tree biodiversity is altered by increased human intervention in natural habitats, fragmentation and loss of fertile soils, the introduction of new species in urban areas, climate change and many more [KOWARIK, 2011]. LOVELESS \& HAMRICK (1984) suggested that genetic variations in plant populations are considered to be shaped by location and time. Trees resistance is supported by its lifespan, phenotypic plasticity, and gene diversity among populations. Up to date, the genetic studies realized with Tilia species have been limited [LIESEBACH \& SINKO, 2008; FILIZ \& al. 2015]. Thus, in this study, the genetic variations of $T$. tomentosa genotypes were investigated by using RAPD markers.

In this study, polymorphic bands and the average population diversity were found to be high in $T$. tomentosa by using nine different RAPD primers. In a similar study, conducted with $T$. rubra populations from the north of Iran, polymorphic bands and average population diversity were found to be $41.4 \%$ and 0.22 , respectively, by using seven RAPD primers [COLAGAR \& al. 2013]. In another study, T. cordata, T. platyphyllos, T. dasystyla, T. euchlora, T. europaea, T. tomentosa, T. americana, 36 genotypes were genotyped using 17 RAPD primers that yielded 403 polymorphic bands [LIESEBACH \& SINKO, 2008]. Results were comparable with our findings, although higher polymorphism levels are generated by a wide gene pool of different Tilia taxa. Also, FILIZ \& al. (2015) found 53 polymorphic fragments and average population diversity of $94.29 \%$ in T. tomentosa by using eight different RAPD primers. Our results were similar to T. tomentosa previous reports suggesting that eco-geographic characteristics and life history are important factors for genome structure in woody plant species.

The cluster analysis using the UPGMA dendrogram revealed a clear differentiation among genotypes based on geographical origin (Figure 1). The principal component analysis confirmed the UPGMA tree data and clustered P7 separately. As expected, P1 to P6 clustered together in the PCA. Clonal propagation results in the reduction of genotypic diversity and population differentiation, but, on the other hand, may increase heterozygosity [BALLOUX $\&$ al. 2003]. Moreover, asexual multiplication is critical for studying the effects of heterozygosity and genetic structure [HALKETT \& al. 2005]. Most Tilia taxa are produced 
through vegetative reproduction, summing approx. $77 \%-80 \%$ of the young trees in the southwest region of Russia and almost $100 \%$ in the north-east region of Europe [FILIZ \& al. 2015].

\section{Conclusions}

The high rates of asexual reproduction of $T$. tomentosa could be clearly seen in the UPGMA tree and PCA results. Similar genetic structures could also explain the origin of $T$. tomentosa individuals as some are influenced by eco-geographical factors. A further breeding effort for Tilia trees should focus on crossings between parental lines with high-stress tolerance and adequacy to urban environments. Furthermore, the ability for vegetative multiplication should be included in the selection criterions for breeding purposes. Further studies are necessary for a good classification of reference material and further taxonomic investigation. New developments in the area of the molecular marker should be included used to obtain reliable results and sustainable outcomes, according to breeding objectives.

\section{Notes on contributors}

Iulian GABUR - is an Assistant Professor at the University of Agricultural Sciences and Veterinary Medicine from Iaşi, Faculty of Agriculture, Discipline of Plant Breeding and Biotechnologies, with a Ph.D. in plant breeding and competences in molecular genetics, molecular markers technologies, PCR, qPCR, genetic mapping, genetic diversity studies, biotechnologies.

Florin Daniel LIPŞA - is an Associate Professor Ph.D. at the University of Agricultural Sciences and Veterinary Medicine from Iaşi, Faculty of Agriculture, Discipline of Microbiology, with competences in microbiology, phytopathology, genetic mapping, QTL identification, and biotechnologies.

Lidia ADUMITRESEI - is a Ph.D. at the Botanical Garden of Iaşi, specialized as a Botanist and in Vegetal Morpho-anatomy, culture conditions optimization for growing alpine plants in ex situ, experienced in Plant Physiology, Rosa genus, coordinator of the Biological Section and Ornamental Cabbage Collection.

Cătălin TĂNASE - is a Professor Ph.D. at the Faculty of Biology of the "Alexandru Ioan Cuza" University of Iaşi - Romania, Director of the Botanical Garden of Iasi, with competences in Botany, Conservation of Plant and Fungi Diversity, management of protected areas, culture conditions optimization for growing fungi in situ and ex situ, isolation of fungi with application in bioremediation, phytopathology - structural, physiological and biochemical modifications produced by pathogen fungi.

Dănuț Petru SIMIONIUC - is an Associate professor Ph.D. at the University of Agricultural Sciences and Veterinary Medicine from Iaşi, Faculty of Agriculture, Discipline of Plant Breeding and Biotechnologies, with competences in modern plant breeding methods, molecular markers (RAPDs, AFLPs, SSRs, others) and genetic diversity studies.

\section{References}

BALLOUX F., LEHMANN L. \& DE MEEUS T. 2003. The population genetics of clonal and partially clonal diploids. Genetics. 164(4): 1635-1644.

CHMIELEWSKI W., DMUCHOWSKI W. \& SUPLAT S. 1998. Impact of urban environmental pollution on growth, leaf damage, and chemical constituents of Warsaw urban trees. General Technical ReportPacific Southwest Research Station, USDA Forest Service No. PSW-GTR-166: 215-219.

COLAGAR A. H., YUSEFI M., ZAREI M. \& YOUSEFZADEH H. 2013. Assessment of genetic diversity of Tilia rubra DC. by RAPD analysis in the Hyrcanian forests, north of Iran. Polish Journal of Ecology. 61: 341-348.

DOYLE J. J. \& DOYLE J. L. 1990. Isolation of plant DNA from fresh tissue. Focus. 12: 13-15. 
FILIZ E., BIRBILENER S., OZYIGIT I. I., KULAC S. \& SAKINOGLU ORUC F. C. 2015. Assessment of genetic variations of silver lime (Tilia tomentosa Moench.) by RAPD markers in urban and forest ecosystems. Biotechnology \& Biotechnological Equipment. 29(4): 631-636.

GOWER J. C. 1985. Properties of Euclidean and non-Euclidean distance matrices. Linear algebra and its applications. 67: 81-97

HALKETT F., SIMON J. C. \& BALLOUX F. 2005. Tackling the population genetics of clonal and partially clonal organisms. Trends in Ecology \& Evolution. 20(4): 194-201.

KARNOSKY D. F., GERHOLD H. D. \& COLLINS W. H. 1982. METRIA Projects on species trials and cultivar testing. Journal of Arboriculture. 8: 178-181.

KOWARIK I. 2011. Novel urban ecosystems, biodiversity, and conservation. Environmental Pollution. 159: 1974-1983.

LIESEBACH H. \& SINKO Z. 2008. A contribution to the systematics of the genus Tilia with respect to some hybrids by RAPD analysis. Dendrobiology. 59: 13-22.

LOVELESS M. D. \& HAMRICK J. L. 1984. Ecological determinants of genetic structure in plant populations. Annual Review of Ecology, Evolution, and Systematics. 15: 65-96.

MUIR N. 1984. A survey of the genus Tilia. Plantsman. 5: 206-242.

R CORE TEAM. 2018. R: a language and environment for statistical computing. $\mathrm{R}$ foundation for statistical computing, Vienna. https://www.r-project.org

RAO V. R. \& HODGKIN T. 2002. Genetic diversity and conservation and utilization of plant genetic resources. Plant Cell, Tissue and Organ Culture. 68: 1-19.

SJÖMAN H., ÖSTBERG J. \& BÜHLER O. 2012. Diversity and distribution of the urban tree population in ten major nordic cities. Urban Forestry and Urban Greening. 11: 31-39.

SUKOPP H. \& WURZEL A. 2000. Changing climate and the effects on vegetation in central European cities. Arboricultural Journal. 24: 257-281.

TERHO M. \& HALLAKSELA A. M. 2005. Potential hazard characteristics of Tilia, Betula, Andacer trees removed in the Helsinki city area during 2001-2003. Urban Forestry \& Urban Greening. 3: 113-120.

VENABLES W. N. \& RIPLEY B. D. 2002. Modern Applied Statistics with S, Springer-Verlag, 138 pp.

WERYSZKO-CHMIELEWSKA E., PIOTROWSKA-WERYSZKO K. \& DĄBROWSKA A. 2019. The response of Tilia sp. L. to climate warming in urban conditions - Phenological and aerobiological studies. Urban Forestry \& Urban Greening. 43: 1-10 (art. No. 126369).

http://www.theplantlist.org/tpl1.1/search?q=tilia, accessed on 15.11.2019.

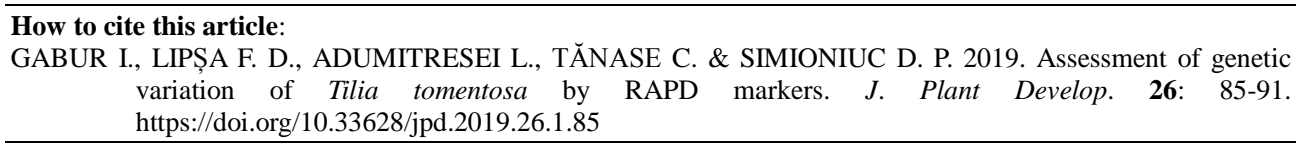

